\title{
Developing and Validating a Japanese Version of the Multidimensional Attitude toward Ambiguity Scale (MAAS)
}

\author{
Jimpei Hitsuwari ${ }^{\circledR}$, Michio Nomura \\ Graduate School of Education, Kyoto University, Kyoto, Japan \\ Email: hitsuwari.jimpei.74x@st.kyoto-u.ac.jp,nomura.michio.8u@kyoto-u.ac.jp
}

How to cite this paper: Hitsuwari, J., \& Nomura, M. (2021). Developing and Validating a Japanese Version of the Multidimensional Attitude toward Ambiguity Scale (MAAS). Psychology, 12, 477-497. https://doi.org/10.4236/psych.2021.124030

Received: February 9, 2021

Accepted: April 9, 2021

Published: April 12, 2021

Copyright ( 2021 by author(s) and Scientific Research Publishing Inc. This work is licensed under the Creative Commons Attribution International License (CC BY 4.0).

http://creativecommons.org/licenses/by/4.0/

\section{(c) (i) Open Access}

\begin{abstract}
As the COVID-19 pandemic clearly shows, we are living in an age of uncertainty and ambiguity. This study develops a Japanese version of the Multidimensional Attitude toward Ambiguity Scale (MAAS), which was originally developed by Lauriola et al. (2016) and has better psychometrics and reproducibility than previously developed personality trait scales for ambiguity. It assesses three factors: discomfort with ambiguity, moral absolutism/splitting, and need for complexity and novelty. To test our newly developed MAAS, we asked 347 participants (147 females and 200 males, $\mathrm{M}_{\text {age }}=39.07, \mathrm{SD}_{\text {age }}=$ 10.58) to complete a back-translated Japanese version of the MAAS online. The Japanese version was found to have sufficient or good internal consistency, retest reliability, and construct validity. We newly found that there were correlations between attitudes toward ambiguity and several scales (e.g., subscales of the Five Facet Mindfulness Questionnaire and the Minimalist Well-Being Scale), and that there are differences in the scores of our Japanese study participants and the Italian samples in the literature. We hope that our Japanese version of the MAAS will be actively used in future cross-cultural comparative research.
\end{abstract}

\section{Keywords}

Multidimensional Attitude Toward Ambiguity, Ambiguity Tolerance, Intolerance of Uncertainty, Need for Cognitive Closure, Cross-Cultural Research

\section{Introduction}

The spread of the COVID-19 pandemic and the ambiguity and uncertainty surrounding the spread of the virus via misinformation and confusing, contradic- 
tory government policies have had a great impact on people's mental well-being and their attitudes toward world events (e.g., Koffman et al., 2020). It has demonstrated the need to examine the psychological mechanisms behind people's responses to ambiguity and uncertainty (Salvi et al., 2021). Below, we examine how these mechanisms have been studied in the literature to give some background for this study's development and validation of a Japanese version of the Multidimensional Attitude toward Ambiguity Scale (MAAS).

\subsection{Ambiguity Tolerance}

Since Frenkel-Brunswik (1949) first coined the concept of ambiguity tolerance, the concept has been studied and applied in various fields, including cognitive psychology, clinical psychology, medicine, and organizational behavior (Furnham \& Marks, 2013). Research on ambiguity tolerance has focused on people's negative attitudes toward ambiguous situations (Nishimura, 2007) by measuring aspects such as their intolerance of uncertainty-defined as "the tendency to perceive ambiguous situations as a source of threat" (Budner, 1962: p. 29). Therefore, studies of ambiguity tolerance have also examined the relationship between low levels of ambiguity tolerance and social anxiety (Boelen \& Reijntjes, 2009), worry (Buhr \& Dugas, 2006), and stress evaluation (Iannello et al., 2017; Masuda, 1998). Other scholars have not framed ambiguity tolerance as perception of a threat; McLain (1993) suggested that it represents "a range, from rejection to attraction, of reactions to stimuli perceived as unfamiliar, complex, dynamically uncertain, or subject to multiple conflicting interpretations" (p. 184). Following McLain, some researchers have emphasized the relationship between ambiguity tolerance and people's attraction to or desire for ambiguity and have found that high ambiguity tolerance is robustly correlated with openness to experience (Jach \& Smillie, 2019), preferences for certain genres of art (Furnham \& Avison, 1997; Swami et al., 2010), and is associated with sensation seeking (McLain, 2009). These studies have largely used subjective self-reporting scales. By 2013, roughly eight such scales had been developed-however, their psychometric quality is rather low (Furnham \& Marks, 2013).

\subsection{Scales to Measure Ambiguity Tolerance}

Lauriola et al. (2016) proposed the Multidimensional Attitude toward Ambiguity Scale (MAAS) in response to these aforementioned problems. The MAAS is a high quality scale derived from a factor analysis of the hierarchical structure of 133 items from seven other ambiguity tolerance scales. It assesses people's multidimensional attitudes toward ambiguity via three subscales: their discomfort with ambiguity (DA), moral absolutism/splitting (MA), and need for complexity and novelty (NC).

The DA represents a negative attitude toward or intolerance of ambiguity. High scores on this subscale are positively related to social anxiety (Boelen \& Reijntjes, 2009), stress appraisal (Iannello et al., 2017), negative affect (Bardi et 
al., 2009; Iannello et al., 2020), and neurotic tendencies regarding the Big Five personality traits (Jach \& Smillie, 2019; Matthews et al., 2018). The MA refers to the attitude of judging things in a binary, "black and white" manner. People with high MA scores tend to try to eliminate ambiguity. The MA is related to the need for cognitive completion, or a "desire for definite knowledge on some issue and the eschewal of confusion and ambiguity" (Kruglanski \& Webster, 1996: p. 278). van Zyl's (2020) study examined the relationship between high MA scores and cognitive tasks. This study found that MA (but not DA or NC) negatively predicted study participants' performance on the Cognitive Reflection Test (CRT) and belief-bias syllogisms (BB), and that participants with higher MA scores performed worse on these tasks (van Zyl, 2020). In contrast to DA and MA, NC refers to people's positive attitudes toward complexity, novelty, and ambiguity (Budner, 1962). High NC scores are associated with openness and extraversion (Jach \& Smillie, 2019) and are also thought to be related to positive emotions (Bardi et al., 2009), a tendency toward mindfulness (Le et al., 2012), and a high tolerance of ambiguity.

By capturing people's multidimensional attitudes toward ambiguity, the MAAS helps researchers examine people's attitudes toward ambiguity from multiple perspectives rather than merely assessing whether people view ambiguity as positive or negative. These three subscales also reflect the affective (DA), cognitive (MA), and epistemic (NC) aspects of people's attitudes toward ambiguity (Lauriola et al., 2016), and have been applied in this manner in the literature (Childers et al., 2020 for NC; Matthews et al., 2018 for DA; Salvi et al., 2021 for MA). Although the MAAS is valid and reliable, there is no Japanese version of the MAAS available. This study, thus, fills a practical and theoretical gap by developing and validating a Japanese version of the MAAS.

\subsection{Limitations of Other Japanese Scales Measuring Ambiguity Tolerance}

Other ambiguity tolerance scales are already used in Japan. For instance, researchers created the Ambiguity Tolerance Scale IV (ATS-IV) based on the items of foreign versions scales developed by Norton (1975) and created a one-dimensional factor structure (Imagawa, 1981). However, Nishimura and Kitayama (2001) found that this scale had not one but two dimensions, that is, the results of factor analysis were not consistent. In addition, it was translated nearly 40 years ago, therefore, the wording of the items needs to be updated, and with its 44 items it is difficult and time-consuming to fill out. Although an original Japanese version of the scale exists (Nishimura, 2007; Tomono \& Hashimoto, 2005), it is difficult to make cross-cultural comparisons between scales that have different items and factor structures. Cross-cultural comparisons are important because attitudes toward ambiguity might be culturally determined and include differences between Eastern and Western populations (Bottesi et al., 2016; Gelfand et al., 2011; Lauriola et al., 2016; Spector et al., 2001). Thus, by 
creating a Japanese version of the MAAS - a scale which is already widely used overseas-the authors hope to facilitate cross-cultural comparisons and research. The scale has already been translated into Italian (Lauriola et al., 2016) and Swedish (Forsberg et al., 2019), and translations into other languages are in progress.

\subsection{Purpose of This Study}

This study aims to create a Japanese version of the MAAS devised by Lauriola et al. (2016) and verify its reliability and validity. First, we will check whether the back-translated Japanese version of the MAAS has the same factor structure as the original. Second, we will conduct a survey using our new MAAS to confirm its re-test reliability and compare its construct validity with other scales. Throughout, we place emphasis on the strength of the scale to make it more suitable for cross-cultural comparison.

\section{Method and Measures}

This study was conducted after ethical review by the Graduate School of Education, Kyoto University (Acceptance Number: CPE-379).

\subsection{Participants}

We recruited 400 study participants through Crowdworks (https://crowdworks.jp/). Of these, we analyzed the survey responses of 385 participants (159 females and 226 males, $\mathrm{M}_{\text {age }}=38.63, \mathrm{SD}_{\text {age }}=10.48$ ) - we arrived at this number by excluding participants with the same IP address, extremely short response times (less than five minutes), and those who failed to answer the attention check correctly. To assess the reliability of our Japanese MAAS, we conducted a re-test by asking our study participants to answer the same questionnaire one week later. After linking the data between the two test days, we found that we had a total 347 participants (147 females and 200 males, $\mathrm{M}_{\text {age }}=39.07, \mathrm{SD}_{\text {age }}=10.58$ ).

\subsection{Procedure}

We made the questionnaire using Qualtrics (https://www.qualtrics.com/) and the participants entered responses to the questionnaire on Crowdworks. The questionnaire began by asking for the participants' demographic data (gender, age, nationality, level of education attained, etc.), followed by the 30-item Japanese version of the MAAS (MAAS-J). After that, to examine construct validity, participants responded to seven scales known to be associated with attitudes toward ambiguity in a randomized order (see scales, below). The questionnaire items for these questionnaires were also randomized. It took about 10 - 15 minutes to answer the questionnaires and participants were paid 150 yen for their time.

\subsection{Multidimensional Attitude toward Ambiguity Scale}

The authors of this paper translated the MAAS into Japanese with the permis- 
sion of the original authors. We tried to be faithful to the original version's intent. We then used a translation service (NAI Inc.; https://www.nai.co.jp/) to back-translate a provisional Japanese version of the MAAS. Finally, we had the original authors confirm that the back-translated version of the MAAS-J was equivalent to the original English version.

Then, after several preliminary surveys of 100 - 150 participants each, we made a minor correction to the items. These surveys found that the original 30-item MAAS-J had low factor loadings and that many items were dropped. They also found that a shortened, 21-item version of the MAAS-J had better factor integration. Therefore, we decided to use this shortened version in our main study (for the model fit, items, and factor analysis of the 30-item version of the MAAS-J, please refer to Supplementary Table 1 and Table 2). Like the MAAS, the MAAS-J consists of three factors-DA, MA, and NC. Survey respondents were asked to rate their attitudes toward various ambiguous situations on a seven-point Likert-type scale, where responses ranged from "completely disagree" to "strongly agree". The 21 -item version in Japanese can be found in the supplementary file.

\subsection{Short Form of the Big Five Scale}

This scale is a short version of the Big Five Scale (BFS) developed by Wada (1996). The BFS was developed from a translation of the Adjective Check List (ACL) developed by Gough and Heilbrun (1965). The short version of the BFS, which includes five items related to neuroticism, five items related to extraversion, and six items related to openness, was used. This version has been confirmed to have factorial validity, internal consistency, and comorbid validity (Namikawa et al., 2012). Previous studies have found that DA is positively correlated with neuroticism and negatively correlated with extraversion and openness, MA negatively correlated with openness, and NC positively correlated with extraversion and openness (Lauriola et al., 2016). We expect to find similar correlations in the present study.

\subsection{Need for Closure Scale}

The Need for Closure Scale (NFC) is used to measure people's need for cognitive closure. The original version of this scale, developed by Webster and Kruglanski (1994), had 41 items with five factors. In this study, we used the Japanese version developed by Suzuki and Sakurai (2003). The Japanese version of the NFC has 20 items and a three-factor structure (Neuberg et al., 1997). The three factors are decisiveness, preference for order (PFO), and preference for predictability (PFP). The internal consistency, re-test reliability, and construct validity of the Japanese version of the NFC have all been confirmed. Participants were asked to rate their agreement with each item on a seven-point Likert-type scale with responses ranging from "completely disagree" to "strongly agree". The need for cognitive closure is considered to be similar to ambiguity tolerance and intolerance of 
Table 1. Fit indices of the confirmatory factor analysis for the 21-item MAAS-J.

\begin{tabular}{|c|c|c|c|c|c|c|c|c|c|}
\hline & Chisq & $\mathrm{df}$ & $\mathrm{p}$ value & GFI & AGFI & NFI & CFI & RMSEA & AIC \\
\hline \multicolumn{10}{|l|}{ 21-item ver. } \\
\hline Three factors, DA, MA, NC, uncorrelated & 427.73 & 189 & 0.00 & 0.904 & 0.883 & 0.810 & 0.883 & 0.057 & $25,766.53$ \\
\hline Three factors, DA, MA, NC, correlated & 405.23 & 186 & 0.00 & 0.908 & 0.886 & 0.820 & 0.892 & 0.055 & $25,750.04$ \\
\hline
\end{tabular}

Note. Chisq = chi square; GFI = goodness of fit index; AGFI = adjusted GFI; NFI = normed fit index; CFI = comparative fit index; RMSEA = root mean square error of approximation; AIC = Akaike's information criterion.

Table 2. Result of the confirmatory factor analysis for the 21-item MAAS-J.

Item No.

Items

Factor Load

Factor 1: Discomfort with Ambiguity (DA) ( $\alpha=0.73)$

3 It intensely disturbs me when I am uncertain of how my actions will affect others.

6 I don't feel comfortable with people until I can find out something about them.

9 I am just a little uncomfortable with people unless I feel that I can understand their behavior.

12 I get pretty anxious when I'm in a social situation involving me which I have little control of.

15 It bothers me when I don't know how other people react to me.

23 If I am uncertain about the responsibilities of a job, I get very anxious.

29 If I don't get the punch line of a joke, I don't feel right until I understand it.

Factor 2: Moral Absolutism/Splitting (MA) ( $\alpha=0.75)$

1 There are two kinds of people in the world: the weak and the strong.

4 A person either knows the answer to a question or he doesn't.

0.802

7 There are two kinds of people: the "good" and the "bad".

0.996

10 You can classify almost all people as either honest or crooked.

0.992

19 There's a right way and a wrong way to do almost everything.

0.527

26 A person is either a $100 \%$ patriotic or he isn't.

30 Our thinking would be a lot better off if we would just forget about words like "probably," "approximately," "perhaps".

Factor 3: Need for Complexity and Novelty (NC) $(\alpha=0.84)$

2 I pursue problem situations which are so complex some people call them "mind boggling".

8 I'm drawn to situations which can be interpreted in more than one way.

14 Vague and impressionistic pictures appeal to me more than realistic pictures.

0.360

17 I tend to like obscure or hidden symbolism.

0.550

20 Some problems are so complex that just trying to understand them is fun.

25 It is more fun to tackle a complicated problem than to solve a simple one.

28 I enjoy tackling problems which are complex enough to be ambiguous.

0.789

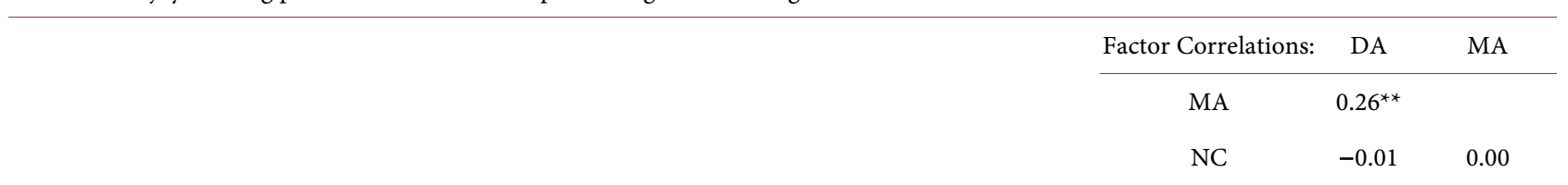


uncertainty and has been correlated with scales that measure NFC (Gärtner et al., 2020). Among the three factors, PFO and PFP are correlated with a tendency toward a lack of ambiguity and decisiveness is correlated with making quick, confident decisions, and not being perturbed by ambiguity. We expect to find MA and DA to be positively correlated with PFO and PFP and negatively correlated with decisiveness and expect to find the opposite for NC.

\subsection{Positive and Negative Affect Schedule}

The Positive and Negative Affect Schedule (PANAS) was developed by Watson et al. (1988) to measure positive affect (PA) and negative affect (NA). A Japanese version of the PANAS was developed by Sato and Yasuda (2001). The original version consisted of 20 items with 10 items each; the Japanese version contains only 16 items with eight items each by deleting items which had low factor loadings. The validity of this scale has been confirmed using the internal consistency and imagery methods. Participants responded to each item using a six-point Likert-type scale with answers ranging from "not true at all" to "very true". Previous studies have found that intolerance of ambiguity is negatively correlated with PA and positively correlated with NA (Bardi et al., 2009; Iannello et al., 2020). We expect to find DA to be positively correlated with NA and NC to be positively correlated with PA.

\subsection{State Trait Anxiety Inventory}

The State Trait Anxiety Inventory (STAI) was developed by Spielberger et al. (1970). It consists of 20 items for state anxiety and 20 items for trait anxiety. A Japanese version of the STAI was developed by Nakazato and Mizuguchi (1982), and they confirmed the internal consistency, re-test reliability, and construct validity of this scale have been confirmed by previous studies. Participants were asked to answer each item using a four-point Likert-type scale with answers ranging from "almost never" to "frequently". Bardi et al.'s (2009) study found that there is a positive correlation between intolerance of ambiguity and trait anxiety, therefore, we expect to find a positive correlation between trait anxiety and $\mathrm{DA}$ and a negative correlation between trait anxiety and NC.

\subsection{Five Facet Mindfulness Questionnaire}

The Five Facet Mindfulness Questionnaire (FFMQ), developed by Baer et al. (2006), is a 39-item scale used to multidimensionally assess trait mindfulness. A Japanese version of this scale was developed by Sugiura et al. (2012), and they have the internal consistency and construct validity of this scale. The Japanese version consists of 39 items with five factors: observing, describing, acting with awareness (AWA), non-judging (NJ), and non-reactivity (NR). Participants were asked to answer each item on a five-point Likert-type scale with answers ranging from "never" to "always". Previous studies have found correlations between high ambiguity tolerance and mindfulness (Fulton, 2016; Le et al., 2012; Robinson, 
2019). We expect to find negative correlations between mindfulness and DA and positive correlations between mindfulness and NC. Since previous studies have not examined the correlation between the multidimensional measures of mindfulness and attitudes toward ambiguity, we also explore the correlation between each subscale to facilitate comparative research. We expect MA to be negatively correlated with NJ.

\subsection{Satisfaction with Life Scale}

The Satisfaction With Life Scale (SWLS), developed by Diener et al. (1985), is a five-item scale used to measure subjective life satisfaction. A Japanese version of the SWLS was developed by Sumino (1994), and they confirmed the internal consistency, re-test reliability, and construct validity of this scale. Participants answered each item using a seven-point Likert-type scale with answers ranging from "strongly disagree" to "strongly agree". Since negative attitudes toward ambiguity are known to be associated with low life satisfaction (Bardi et al., 2009; Iannello et al., 2020), we expect a negative correlation between life satisfaction and DA and a positive correlation between life satisfaction and NC.

\subsection{Minimalist Well-Being Scale}

The Minimalist Well-Being Scale (MWBS), developed by Kan et al. (2009), is a 12-item scale used to measure a minimalist (i.e., non-material or consumption-driven) sense of well-being. The original version of the scale had a two-factor structure-the factors were peaceful disengagement (PD) and gratitude. However, the Japanese version of the scale developed by Horike and Ohshima (2015) has a four-factor structure. The factor structures are not consistent, so the total score of the entire scale is used here. The internal consistency and criterion-related validity of this scale have been confirmed by previous research (Kan et al., 2009). Respondents were asked to answer each item using a seven-point Likert-type scale with answers ranging from "I strongly disagree" to "I strongly agree". We hope to expand our knowledge of the interaction between well-being and attitudes toward ambiguity by measuring the relationship between attitudes toward ambiguity and life satisfaction. We expect to find a correlation between ambiguity tolerance and life satisfaction.

\section{Results}

\subsection{Examination of Factor Structure}

When devising the original MAAS, Lauriola et al. (2016) examined a bi-factor model including a general factor of attitude toward ambiguity in addition to the three-factor structure of DA, MA, and NC. Following the original version, we conducted both confirmatory factor analysis using only three factors and confirmatory factor analysis including general factors for the MAAS-J. The results showed that the model fit well (Table 1). Table shows the contents and factor 
loadings of the 21-item version of the MAAS-J. Only item 14 had a factor loading below 0.40 . We also examined the model fit and factor loadings for the 20 items that were deleted from the original MAAS (see Supplementary Table S1 and Table S2), but there was no significant difference in the values. Since we believe that a scale which is faithful to the original version is more useful for cross-cultural comparisons, we analyzed the 21-item MAAS-J because it is considered to have the same structure as the original version.

\subsection{Examination of Reliability and Descriptive Statistics}

The results of the factor analysis indicated that the MAAS-J has a three-factor structure consistent with that of the original version, therefore, the reliability and the descriptive statistics of each factor were examined. We calculated the Cronbach's alpha coefficients for the internal consistency of each subscale of the MAAS-J. We found sufficient or good internal consistency was found for each subscale (DA: $\alpha=0.73$; MA: $\alpha=0.75$; NC: $\alpha=0.84$ ), as shown in Table 3. In addition, the results of the analysis of the correlations among the subscales for the re-test reliability, conducted after a one-week interval, showed sufficient or good re-test reliability (DA: $r=0.69, p<0.01$; MA: $r=0.73, p<0.01$; NC: $r=0.83, p<$ 0.01). We also calculated the Cronbach's alpha of the data at the second time point; it also showed sufficient or good internal consistency (DA: $\alpha=0.78$; MA: $\alpha=0.80$; NC: $\alpha=0.89$ ). The factor structure of the MAAS-J was also consistent with the original version, except for one item that was below 0.40 (the factor loading for item 30 was 0.377 ).

Table 3 shows the descriptive statistics of each factor in the MAAS-J. Table 3 also includes the means and standard deviations for the Italian sample from the original MAAS. The results showed that the Japanese sample scored higher than the original Italian sample on the two factors DA ( $t=10.42, p<0.01, d=0.73$ ) and MA $(t=2.25, p=0.02, d=0.15)$, and the Italian sample scored higher than the Japanese sample on NC $(t=-11.20, p<0.01, d=0.80)$.

\subsection{Examination of Construct Validity}

To verify the construct validity of the MAAS-J, we conducted a correlation analysis between the MAAS-J and each scale. The results were generally consistent with our expectations (Table 4). First, the correlations between DA and the scales that were expected to be related to DA were as follows: neuroticism $(r=$ $0.46, p<0.01)$, extraversion $(r=-0.20, p<0.01)$, openness $(r=-0.14, p=0.01)$, decisiveness $(r=-0.40, p<0.01)$, PFP $(r=0.27, p<0.01)$, PA $(r=-0.17, p<$ $0.01)$, NA $(r=0.29, p<0.01)$, STAI $(r=0.45, p<0.01)$, decisiveness $(r=-0.40$, $p<0.01)$, and PFO $(r=0.27, p<0.01)$, FFMQ $(r=-0.37, p<0.01)$, observing $(r$ $=0.13, p=0.01)$, describing $(r=-0.20, p<0.01)$, AWA $(r=-0.32, p<0.01)$, NJ $(r=-0.39, p<0.01)$, NR $(r=-0.28, p<0.01)$, SWLS $(r=-0.19, p<0.01)$, and MWBS $(r=-0.16, p<0.01)$. In contrast, there was no significant correlation between DA and PFO $(r=-0.02, p=0.70)$. 
Table 3. Descriptive statistics for MAAS-J subscales and total scores.

\begin{tabular}{|c|c|c|c|c|c|c|c|}
\hline & \multicolumn{2}{|c|}{ Day-1 data $(N=385)$} & \multicolumn{2}{|c|}{ Day-2 data $(N=347)$} & \multicolumn{3}{|c|}{$\begin{array}{l}\text { Lauriola et al. (2016) Italian data for } \\
\text { comparison }(N=405)\end{array}$} \\
\hline & $\mathrm{M}(\mathrm{SD})$ & $\alpha$ & $\mathrm{M}(\mathrm{SD})$ & $\mathrm{r}$ & $\mathrm{M}(\mathrm{SD})$ & $\mathrm{t}$ & $\mathrm{d}$ \\
\hline Discomfort with Ambiguity & $4.62(0.80)$ & 0.73 & $4.71(0.83)$ & 0.69 & $3.88(1.18)$ & 10.42 & 0.73 \\
\hline Moral Absolutism & $3.62(0.86)$ & 0.75 & $3.59(0.88)$ & 0.73 & $3.45(1.38)$ & 2.25 & 0.15 \\
\hline Need for Complexity & $3.78(0.96)$ & 0.84 & $3.79(1.02)$ & 0.83 & $4.58(1.05)$ & -11.20 & 0.80 \\
\hline
\end{tabular}

Note. The figure " $r$ " shows correlation between day-1 mean and day- 2 mean (i.e., re-test reliability).

Table 4. Means (M) and standard deviations (SD) of the scales used for construct validity, and the correlations with MAAS-J.

\begin{tabular}{|c|c|c|c|c|c|}
\hline & $\mathbf{M}$ & $\mathrm{SD}$ & DA & MA & NC \\
\hline \multicolumn{6}{|l|}{ Demography } \\
\hline Age & 38.63 & 10.48 & -0.08 & -0.05 & -0.06 \\
\hline Sex & 1.59 & 0.49 & 0.01 & -0.12 & -0.14 \\
\hline Education & 3.30 & 0.93 & -0.04 & -0.12 & 0.01 \\
\hline \multicolumn{6}{|l|}{ Big Five } \\
\hline Neuroticism & 4.85 & 1.26 & 0.46 & -0.04 & -0.11 \\
\hline Extraversion & 3.69 & 1.26 & -0.20 & 0.06 & 0.15 \\
\hline Openness & 4.03 & 1.09 & -0.14 & 0.04 & 0.44 \\
\hline \multicolumn{6}{|l|}{ Need for Cognitive Closure } \\
\hline Decisiveness & 3.55 & 1.11 & -0.40 & 0.03 & 0.18 \\
\hline Preference for Order (PFO) & 4.45 & 0.85 & -0.02 & 0.09 & 0.00 \\
\hline Preference for Predictability (PFP) & 4.46 & 1.17 & 0.27 & -0.05 & -0.39 \\
\hline \multicolumn{6}{|l|}{ PANAS } \\
\hline Positive Affect (PA) & 2.80 & 0.86 & -0.17 & 0.14 & 0.19 \\
\hline Negative Affect (NA) & 2.78 & 1.09 & 0.29 & 0.03 & 0.02 \\
\hline STAI & 2.55 & 0.59 & 0.45 & 0.07 & -0.04 \\
\hline FFMQ & 3.01 & 0.37 & -0.37 & -0.06 & 0.21 \\
\hline Observing & 2.96 & 0.64 & 0.13 & 0.03 & 0.29 \\
\hline Describing & 2.82 & 0.72 & -0.20 & 0.04 & 0.26 \\
\hline Acting with Awareness (AWA) & 3.40 & 0.65 & -0.32 & -0.11 & -0.05 \\
\hline Non Judging (NJ) & 3.08 & 0.65 & -0.39 & -0.14 & -0.10 \\
\hline Non Reactivity (NR) & 2.78 & 0.58 & -0.28 & -0.01 & 0.19 \\
\hline Satisfaction With Life Scale (SWLS) & 3.52 & 1.44 & -0.19 & -0.09 & 0.13 \\
\hline Minimalist Well Being Scale (MWBS) & 4.74 & 0.90 & -0.16 & -0.03 & 0.15 \\
\hline
\end{tabular}

Note. Bold indicates a significant difference $(p<0.05)$. For sex, 1 is male and 2 is female. 
The correlations between MA and the predicted scales were significant for AWA $(r=-0.11, p=0.04)$, NJ $(r=-0.14, p<0.01)$, and PFO $(r=0.09, p=$ $0.06)$, while the correlations between MA and openness $(r=0.04, p=0.41)$, decisiveness $(r=0.03, p=0.54)$, PFP $(r=-0.05, p=0.35)$, FFMQ $(r=-0.06, p=$ $0.21)$, observing $(r=0.03, p=0.56)$, describing $(r=0.04, p=0.45)$, and NR $(r=$ $-0.01, p=0.91)$ were not significant. There was also a significant positive correlation between MA and PA $(r=0.14, p<0.01)$, and a significant negative correlation between MA and SWLS $(r=-0.09, p=0.09)$, neither of which were expected.

Finally, the correlations between NC and the predicted scales were as follows: neuroticism $(r=-0.11, p=0.03)$, extraversion $(r=0.15, p<0.01)$, openness $(r=$ $0.44, p<0.01)$, decisiveness $(r=0.18, p<0.01)$, PFP $(r=-0.39, p<0.01)$, PA $(r$ $=0.19, p<0.01)$, FFMQ $(r=0.21, p<0.01)$, observing $(r=0.29, p<0.01)$, describing $(r=0.26, p<0.01)$, NJ $(r=-0.10, p=0.04)$, NR $(r=0.19, p<0.01)$, SWLS $(r=0.19, p<0.01)$, and MWBS $(r=0.15)$. However, there was no significant correlation between NC and PFO $(r=0.00, p=0.93)$, NA $(r=0.02, p=$ $0.65)$, STAI $(r=-0.04, p=0.40)$, and AWA $(r=-0.05, p=0.29)$.

\section{Discussion}

\subsection{Factor Structure and Reliability}

The results of our factor analysis and model comparison showed that the MAAS-J's structure and items were comparable to the original MAAS. Specifically, the bi-factor model, which assumes three factors (DA, MA, NC) and general factors, showed the best model fit $\left(X^{2}=307.91\right.$, GFI $=0.931$, AGFI $=0.901$, $\mathrm{NFI}=0.863$, CFI $=0.928, \mathrm{RMSEA}=0.048, \mathrm{AIC}=25,700.71)$. Since the models are similar, we can conclude that the MAAS-J can effectively classify Japanese people's attitudes toward ambiguity as per the three main factors in the original model and the MAAS-J can be used to examine relationship between these factors and other scales. The MAAS-J also showed good internal reliability (DA: $\alpha=$ 0.73; MA: $\alpha=0.75$; NC: $\alpha=0.84$ ) and re-test reliability (DA: $r=0.69$; MA: $r=$ 0.73 ; NC: $r=0.83$ ).

\subsection{Construct Validity}

Since we found the expected correlations when comparing the MAAS-J with related scales, we consider the MAAS-J to have sufficient construct validity. First, we found that neuroticism in the BFS was moderately correlated with DA and weakly correlated with NC, and that trait anxiety and DA were moderately correlated. The two scales showed a moderate correlation of $r>0.40$. These findings are consistent with previous studies on intolerance of uncertainty, which showed that intolerance of uncertainty and anxiety are similar but different (Bardi et al., 2009). Extroversion and openness in the BFS were negatively correlated with DA and positively correlated with NC, while MA was not well characterized in BFS, similar to the findings of previous studies (Lauriola et al., 2016). 
We also found that NA was positively correlated with DA and that PA was negatively correlated with DA and positively correlated with MA and NC. This finding is corroborated by previous studies (Bardi et al., 2009; Iannello et al., 2020) in which intolerance of ambiguity was positively correlated with NA and negatively correlated with PA. The fact that MA was weakly but unexpectedly associated with PA suggests that people whose attitudes favor black-and-white, conclusive, and unambiguous judgements may be more adaptive and associated with PA in Japanese culture, which is driven by conformity to norms.

We also found that well-being was negatively correlated with DA and positively correlated with NC, albeit to a weak extent. These results are consistent with the concepts that DA indicates a negative attitude toward ambiguity and NC indicates a positive attitude. Given that the ease with which people hold positive emotions is linked to their well-being (Fredrickson \& Joiner, 2002), it is reasonable that well-being is negatively correlated with DA and positively correlated with NC. Furthermore, our multiple regression analysis with SWLS as the dependent variable and DA and PA as the independent variables showed that the effect of DA on well-being was still significant $(b=-0.23, \beta=-0.13, S E=0.09, t$ $=-2.72, p<0.01)$. Although weakly correlated, the MWBS also showed a negative correlation with DA and a positive correlation with NC. Our finding that people's attitude toward ambiguity leads to their well-being in relation to the MWBS-which is considered to be a more appropriate measure of Japanese people's well-being (Kan et al., 2009) —is novel.

We also found that mindfulness as measured by the FFMQ was negatively correlated with DA and positively correlated with NC. These results are consistent with previous studies that have shown a relationship between tolerance of ambiguity and mindfulness (Fulton, 2016; Le et al., 2012; Robinson, 2019). Although the five subscales of the FFMQ were correlated generally in the same direction as the total score, it is worth noting that observing was positively correlated with DA and NJ was negatively correlated with both MA and NC. The FFMQ's bi-factor model of FFMQ does not fit the observing factor, suggesting its specificity (Baer et al., 2006, 2008). Since we first "observe" the subject and then judge the ambiguity as positive or negative, the "observing" factor was positively correlated with both DA and NC. We also found that NJ was negatively correlated with MA, which was not correlated with the FFMQ total score (as hypothesized). This suggests that MA attitudes and mindfulness are opposites. NJ was also negatively (but weakly) correlated with NC, proving that NC represents the epistemic aspect of people's attitudes toward ambiguity (Lauriola et al., 2016).

Regarding NFC, we found that decisiveness was negatively correlated with DA and positively correlated with NC and that PFP was positively correlated with DA and negatively correlated with NC. The decisiveness subscale included items such as, "I usually make important decisions quickly and confidently," which may indicate a tendency to avoid or eliminate ambiguity. Therefore, we find it 
reasonable that decisiveness was associated with DA and NC but not with MA. Similarly, because PFP reflects a preference for predictability, we feel that its association with DA and NC is reasonable as well. Although people's need for cognitive closure and their intolerance of ambiguity have been thought of as similar concepts (Iannello et al., 2017; Kruglanski \& Webster, 1996), the results here confirm the discriminant validity of these concepts as being distinct.

However, not many scales showed a significant correlation with MA, and the construct validity of MA needs to be investigated further. The MA indicates a dichotomous attitude toward ambiguity, so we expected that it would be related to people's need for cognitive closure. However, in this study, a significant (but weak) correlation was found only between MA and PFO. In the present study, MA was positively correlated with PA $(r=0.14, p<0.01)$ and PFP was negatively correlated with PA $(r=-0.22, p<0.01)$. In other words, the findings suggest that MA is a positive attitude and PFP in NFC is a negative attitude. Therefore, it is possible that MA and NFC were not as highly correlated as expected. Other scholars have suggested that MA is related to prejudice and political attitudes (Forsberg et al., 2019; Lauriola et al., 2016; Moss \& O'Connor, 2020), therefore, we expect it to be explored in the future and that its validity will be tested with other scales.

\section{Conclusion}

This study successfully developed and validated a Japanese version of the MAAS. However, it has a few limitations. Specifically, our work revealed that cultural differences had an impact on our study participants' responses. Our Japanese study participants had higher DA and MA scores, and Italian study participants from the original MAAS had higher NC scores. The results support the claim that Japan is a so-called tight culture (Mrazek et al., 2013) with a low tolerance for ambiguity compared to Western countries (Gelfand et al., 2011). To date, only a limited number of cross-cultural comparative studies have addressed people's attitudes toward ambiguity. For example, Spector et al. (2001) examined uncertainty avoidance across 23 countries, although the reliability of the scale used in that study is questionable. In that study, Japan had one of the highest ambiguity avoidance scores. Another study that examined intolerance of ambiguity between Italians and British people (Bottesi et al., 2016) showed that Italians were more tolerant of ambiguity. Thus, cultural comparisons of attitudes toward ambiguity have been made only piecemeal and need to be examined more comprehensively in the future.

This study's MAAS-J was both structured in a similar way to the original version and had good internal consistency $(\alpha=0.73-0.85)$, re-test reliability $(r=$ $0.69-0.83$ ), and construct validity. It was able to newly show correlations between people's attitudes toward ambiguity and several similar scales (e.g., subscales in the FFMQ and MWBS). Clear differences between Japanese and Italian samples were shown for the first time. We hope that the Japanese version of this 
scale will assist future cross-cultural comparative research on people's attitudes toward ambiguity and will help to elucidate the psychological mechanisms behind these attitudes. While the MAAS has been established internationally as an appropriate measure of people's attitudes toward ambiguity, limited research has been done on the relationship between these attitudes and people's neural substrates. Considering that functional brain imaging studies of perceived ambiguity have shown that people's attitudes have emotional, cognitive, and epistemic aspects-and considering that these aspects correlate to the DA MA, and NC subscales (Nomura et al., 2003) - we expect the MAAS-J to contribute to future, comprehensive examinations of this kind. Future researchers could extend our research by confirming the validity of the MAAS-J with behavioral and neural indices currently practically being used in medical and educational settings as well as assessing whether and how interventions work in terms of attitudes toward ambiguity (case method, Banning, 2003; art appreciation, Bentwich \& Gilbey, 2017).

\section{Acknowledgements}

The authors wish to thank Marco Lauriola for his help with back translation. This research was supported by Grants-in-Aid for Scientific ResearchKAKENHI-(JSPS KAKENHI Grant Nos. 19H01773).

\section{Conflicts of Interest}

The authors declare no conflicts of interest regarding the publication of this paper.

\section{References}

Baer, R. A., Smith, G. T., Hopkins, J., Krietemeyer, J., \& Toney, L. (2006). Using Self-Report Assessment Methods to Explore Facets of Mindfulness. Assessment, 13, 27-45. https://doi.org/10.1177/1073191105283504

Baer, R. A., Smith, G. T., Lykins, E., Button, D., Krietemeyer, J., Sauer, S. et al. (2008). Construct Validity of the Five Facet Mindfulness Questionnaire in Meditating and Nonmeditating Samples. Assessment, 15, 329-342. https://doi.org/10.1177/1073191107313003

Banning, K. C. (2003). The Effect of the Case Method on Tolerance for Ambiguity. Journal of Management Education, 27, 556-567. https://doi.org/10.1177/1052562903252652

Bardi, A., Guerra, V. M., Sharadeh, G., \& Ramdeny, D. (2009). Openness and Ambiguity Intolerance: Their Differential Relations to Wellbeing in the Context of an Academic Life Transition. Personality and Individual Differences, 47, 219-223. https://doi.org/10.1016/j.paid.2009.03.003

Bentwich, M. E., \& Gilbey, P. (2017). More than Visual Literacy: Art and the Enhancement of Tolerance for Ambiguity and Empathy. BMC Medical Education, 17, 200. https://doi.org/10.1186/s12909-017-1028-7

Boelen, P. A., \& Reijntjes, A. (2009). Intolerance of Uncertainty and Social Anxiety. Journal of Anxiety Disorders, 23, 130-135. https://doi.org/10.1016/j.janxdis.2008.04.007

Bottesi, G., Ghisi, M., Carraro, E., Barclay, N., Payne, R., \& Freeston, M. H. (2016). Re- 
vising the Intolerance of Uncertainty Model of Generalized Anxiety Disorder: Evidence from UK and Italian Undergraduate Samples. Frontiers in Psychology, 7, 1723. https://doi.org/10.3389/fpsyg.2016.01723

Budner, S. (1962). Intolerance of Ambiguity as a Personality Variable. Journal of Personality, 30, 29-50. https://doi.org/10.1111/j.1467-6494.1962.tb02303.x

Buhr, K., \& Dugas, M. J. (2006). Investigating the Construct Validity of Intolerance of Uncertainty and Its Unique Relationship to Worry. Journal of Anxiety Disorders, 20, 222-236. https://doi.org/10.1016/j.janxdis.2004.12.004

Childers, C., Hartman, K., Hiler, J., \& Andzulis, M. (2020) Client Projects: Student Attitudes, Learning Outcomes, and Project Evaluations. Journal of Education for Business, 95, 207-215. https://doi.org/10.1080/08832323.2019.1627996

Diener, E., Emmons, R. A., Larsen, R. J., \& Griffin, S. (1985). The Satisfaction with Life Scale. Journal of Personality Assessment, 49, 71-75. https://doi.org/10.1207/s15327752jpa4901 13

Forsberg, E., Nilsson, A., \& Jørgensen, Ø. (2019). Moral Dichotomization at the Heart of Prejudice: The Role of Moral Foundations and Intolerance of Ambiguity in Generalized Prejudice. Social Psychological and Personality Science, 10, 1002-1010. https://doi.org/10.1177/1948550618817347

Fredrickson, B. L., \& Joiner, T. (2002). Positive Emotions Trigger Upward Spirals toward Emotional Well-Being. Psychological Science, 13, 172-175. https://doi.org/10.1111/1467-9280.00431

Frenkel-Brunswik, E. (1949). Intolerance of Ambiguity as an Emotional and Perceptual Personality Variable. Journal of Personality, 18, 108-143. https://doi.org/10.1111/j.1467-6494.1949.tb01236.x

Fulton, C. (2016). Mindfulness, Self-Compassion, and Counselor Characteristics and Session Variables. Journal of Mental Health Counseling, 38, 360-374. https://doi.org/10.17744/mehc.38.4.06

Furnham, A., \& Avison, M. (1997). Personality and Preference for Surreal Paintings. Personality and Individual Differences, 23, 923-935. https://doi.org/10.1016/S0191-8869(97)00131-1

Furnham, A., \& Marks, J. (2013). Tolerance of Ambiguity: A Review of the Recent Literature. Psychology, 4, 717-728. https://doi.org/10.4236/psych.2013.49102

Gärtner, J., Bußenius, L., Prediger, S., Vogel, D., \& Harendza, S. (2020). Need for Cognitive Closure, Tolerance for Ambiguity, and Perfectionism in Medical School Applicants. BMC Medical Education, 20, 1-8. https://doi.org/10.1186/s12909-020-02043-2

Gelfand, M. J., Raver, J. L., Nishii, L. H., Leslie, L. M., Lun, J., Lim, B. C., Yamaguchi, S. et al. (2011). Differences between Tight and Loose Cultures: A 33-Nation Study. Science, 332, 1100-1104. https://doi.org/10.1126/science.1197754

Gough, H. G., \& Heilbrun, A. B. (1965). The Adjective Check List Manual. Palo Alto, CA: Consulting Psychologists Press. https://doi.org/10.1037/t02310-000

Horike, K., \& Ohshima, N. (2015). Sustainability to Syukanteki Well-Being No Kanren Nitsuite: Web Chousa Niyoru Bunseki Kekka. Eco Philosophy Kenkyu, 9, 139-150. (In Japanese)

Iannello, P., Mottini, A., Tirelli, S., Riva, S., \& Antonietti, A. (2017). Ambiguity and Uncertainty Tolerance, Need for Cognition, and Their Association with Stress. A Study among Italian Practicing Physicians. Medical Education Online, 22, Article ID: 1270009. https://doi.org/10.1080/10872981.2016.1270009

Iannello, P., Sorgente, A., Lanz, M., \& Antonietti, A. (2020). Financial Well-Being and Its 
Relationship with Subjective and Psychological Well-Being among Emerging Adults: Testing the Moderating Effect of Individual Differences. Journal of Happiness Studies, 22, 1385-1411. https://doi.org/10.1007/s10902-020-00277-x

Imagawa, T. (1981). Development of Ambiguity Tolerance Scale: Item Analysis and Its Reliability. Bulletin of Hokkaido University of Education, 32, 79-93. http://s-ir.sap.hokkyodai.ac.jp/dspace/handle/123456789/4860

Jach, H. K., \& Smillie, L. D. (2019). To Fear or Fly to the Unknown: Tolerance for Ambiguity and Big Five Personality Traits. Journal of Research in Personality, 79, 67-78. https://doi.org/10.1016/j.jrp.2019.02.003

Kan, C., Karasawa, M., \& Kitayama, S. (2009). Minimalist in Style: Self, Identity, and Well-Being in Japan. Self and Identity, 8, 300-317. https://doi.org/10.1080/15298860802505244

Koffman, J., Gross, J., Etkind, S. N., \& Selman, L. (2020). Uncertainty and COVID-19: How Are We to Respond? Journal of the Royal Society of Medicine, 113, 211-216. https://doi.org/10.1177/0141076820930665

Kruglanski, A. W., \& Webster, D. M. (1996). Motivated Closing of the Mind: "Seizing" and "Freezing". Psychological Review, 103, 263-283. https://doi.org/10.1037/0033-295X.103.2.263

Lauriola, M., Foschi, R., Mosca, O., \& Weller, J. (2016). Attitude toward Ambiguity: Empirically Robust Factors in Self-Report Personality Scales. Assessment, 23, 353-373. https://doi.org/10.1177/1073191115577188

Le, A., Haller, C. S., Langer, E. J., \& Courvoisier, D. S. (2012). Mindful Multitasking: The Relationship between Mindful Flexibility and Media Multitasking. Computers in $\mathrm{Hu}$ man Behavior, 28, 1526-1532. https://doi.org/10.1016/j.chb.2012.03.022

Masuda, S. (1998). Effects of Ambiguity Tolerance on the Psychological Stress Process. Bulletin of the College of Education, Ibaraki University (Humanities and Social Sciences), 47, 151-163. (In Japanese)

Matthews, G., Reinerman-Jones, L. E., Burke, C. S., Teo, G. W. L., Scribner, D. R. (2018). Nationalism, Personality, and Decision-Making: Evidence from an SJT for Military Multi-National Teaming Scenarios. Personality and Individual Differences, 127, 89-100. https://doi.org/10.1016/j.paid.2018.01.045

McLain, D. L. (1993). The Mstat-I: A New Measure of an Individual's Tolerance for Ambiguity. Educational and Psychological Measurement, 53, 183-189. https://doi.org/10.1177/0013164493053001020

McLain, D. L. (2009). Evidence of the Properties of an Ambiguity Tolerance Measure: The Multiple Stimulus Types Ambiguity Tolerance Scale-II (MSTAT-II). Psychological Report, 105, 975-988. https://doi.org/10.2466/PR0.105.3.975-988

Moss J. T., \& O’Connor, P. J. (2020). Political Correctness and the Alt-Right: The Development of Extreme Political Attitudes. PLoS ONE, 15, e0239259. https://doi.org/10.1371/journal.pone.0239259

Mrazek, A. J., Chiao, J., Blizinsky, K. D., Lun, J., \& Gelfand, M. J. (2013). The Role of Culture-Gene Coevolution in Morality Judgment: Examining the Interplay between Tightness-Looseness and Allelic Variation of the Serotonin Transporter Gene. Culture and Brain, 1, 100-117. https://doi.org/10.1007/s40167-013-0009-x

Nakazato, K., \& Mizuguchi, T. (1982). Development and Validation of Japanese Version of State-TraitAnxiety Inventory. Shinshin-Igaku, 22, 107-112. (In Japanese with English Abstract)

Namikawa, T., Tani, I., Wakita, T., Kumagai, R., Nakane, A., \& Noguchi, H. (2012). De- 
velopment of a Short Form of the Japanese Big-Five Scale, and a Test of Its Reliability and Validity. The Japanese Journal of Psychology, 83, 91-99. (In Japanese) https://doi.org/10.4992/jjpsy.83.91

Neuberg, S. L., Judice, T. N., \& West, S. G. (1997). What the Need for Closure Scale Measures and What It Does Not: Toward Differentiating among Related Epistemic Motives. Journal of Personality and Social Psychology, 72, 1396-1412. https://doi.org/10.1037/0022-3514.72.6.1396

Nishimura, S. (2007). Multi-Dimensional Structure of Attitudes towards Ambiguity. The Japanese Journal of Personality, 15, 183-194. (In Japanese) https://doi.org/10.2132/personality.15.183

Nishimura, S., \& Kitayama, O. (2001). The Effect of Context Production and Ambiguity Tolerance on Understanding of Metaphor. The Psychological Bulletin of Kyusyu University, 2, 107-116.

Nomura, M., Iidaka, T., Kakehi, K., Tsukiura, T., Hasegawa, T., Maeda, Y., \& Matsue, Y. (2003). Frontal Lobe Networks for Effective Processing of Ambiguously Expressed Emotions in Humans. Neuroscience Letter, 348, 113-116. https://doi.org/10.1016/S0304-3940(03)00768-7

Norton, R. W. (1975). Measurement of Ambiguity Tolerance. Journal of Personality Assessment, 39, 607-619. https://doi.org/10.1207/s15327752jpa3906 11

Robinson, J. J. (2019). Mindfulness, Tolerance of Ambiguity, and Attitudes toward Interracial Relationships (Order No. 13426037). ProQuest Dissertations \& Theses A\&I; Publicly Available Content Database (2201863505).

https://search.proquest.com/dissertations-theses/mindfulness-tolerance-ambiguity-atti tudes-toward/docview/2201863505/se-2?accountid=11929

Salvi, C., Iannello, P., Cancer, A., McClay, M., Dunsmoor, J., \& Antonietti, A. (2021). Going Viral: How Fear, Socio-Cognitive Polarization and Problem-Solving Influence Fake News Detection and Proliferation during COVID-19 Pandemic. Frontiers in Communication, 5, Article ID: 562588. https://doi.org/10.3389/fcomm.2020.562588

Spector, P. E., Cooper, C. L., \& Sparks, K. (2001). An International Study of the Psychometric Properties of the Hofstede Values Survey Module 1994: A Comparison of Individual and Country/Province Level Results. Applied Psychology, 50, 269-281. https://doi.org/10.1111/1464-0597.00058

Spielberger, C. D., Gorsuch, R. L., \& Lushene, R. E. (1970). Manual for the State-Trait Anxiety Inventory. Palo Alto, CA: Consulting Psychologists Press.

Sugiura, Y., Sato, A., Ito, Y., \& Murakami, H. (2012). Development and Validation of the Japanese Version of the Five Facet Mindfulness Questionnaire. Mindfulness, 3, 85-94. https://doi.org/10.1007/s12671-011-0082-1

Sumino, Z. (1994). Jinsei ni Taisuru Manzoku Syakudo Nihongoban Sakusei no Kokoromi. The Annual Conference of Japanese Society of Psychology, 58, 192. (In Japanese)

Suzuki, K., \& Sakurai, S. (2003). The Construction, Reliability and Validity of a Japanese Need for Closure Scale. The Japanese Journal of Psychology, 74, 270-275. (In Japanese with English Abstract) https://doi.org/10.4992/ijpsy.74.270

Swami, V., Stieger, S., Pietschnig, J., \& Voracek, M. (2010). The Disinterested Play of Thought: Individual Differences and Preference for Surrealist Motion Pictures. Personality and Individual Differences, 48, 855-859.

https://doi.org/10.1016/j.paid.2010.02.013

Tomono, T., \& Hashimoto, T. (2005). Development of Revised Interpersonal Intolerance of Ambiguity Scale. The Japanese Journal of Personality, 13, 220-230. (In Japanese) https://doi.org/10.2132/personality.13.220 
van Zyl, C. J. (2020). Attitude to Ambiguity as a Predictor of Analytic Thinking. South African Journal of Psychology, 51, 107-120. https://doi.org/10.1177/0081246320953715

Wada, S. (1996). Seikaku Tokusei Yougo wo Mochiita Big Five Scale no Sakusei. The Japanese Journal of Psychology, 67, 61-67. (In Japanese) https://doi.org/10.4992/jipsy.67.61

Watson, D., Clark, L. A., \& Tellegen, A. (1988). Development and Validation of Brief Measures of Positive and Negative Affect: The PANAS Scales. Journal of Personality and Social Psychology, 54, 1063-1070. https://doi.org/10.1037/0022-3514.54.6.1063

Webster, D. M., \& Kruglanski, A. W. (1994). Individual Differences in Need for Cognitive Closure. Journal of Personality and Social Psychology, 67, 1049-1062.

https://doi.org/10.1037/0022-3514.67.6.1049 


\section{Supplementary}

Developing and Validating a Japanese Version of the Multidimensional Attitude toward Ambiguity Scale (MAAS) Supplementary Tables.

Table S1. Fit indices of the confirmatory factor analysis for the 30-item and 20-item of MAAS-J.

\begin{tabular}{|c|c|c|c|c|c|c|c|c|c|}
\hline & Chisq & $\mathrm{df}$ & $\mathrm{p}$ value & GFI & AGFI & NFI & CFI & RMSEA & AIC \\
\hline \multicolumn{10}{|l|}{ 30-item ver. } \\
\hline Three factors, DA, MA, NC, uncorrelated & 1080.55 & 405 & 0.00 & 0.837 & 0.813 & 0.697 & 0.784 & 0.066 & $36,955.41$ \\
\hline Three factors, DA, MA, NC, correlated & 1053.91 & 402 & 0.00 & 0.839 & 0.814 & 0.704 & 0.792 & 0.065 & $36,934.77$ \\
\hline $\begin{array}{l}\text { Bifactor, DA, MA, NC group factors } \\
+ \text { general factor }\end{array}$ & 862.58 & 369 & 0.00 & 0.869 & 0.835 & 0.758 & 0.842 & 0.059 & $36,809.44$ \\
\hline \multicolumn{10}{|l|}{20 -item ver. } \\
\hline Three factors, DA, MA, NC, uncorrelated & 399.43 & 170 & 0.00 & 0.906 & 0.884 & 0.816 & 0.884 & 0.059 & $24,481.82$ \\
\hline Three factors, DA, MA, NC, correlated & 376.97 & 167 & 0.00 & 0.910 & 0.887 & 0.826 & 0.894 & 0.057 & $24,465.36$ \\
\hline $\begin{array}{l}\text { Bifactor, DA, MA, NC group factors } \\
+ \text { general factor }\end{array}$ & 279.05 & 144 & 0.00 & 0.935 & 0.905 & 0.871 & 0.932 & 0.049 & $24,413.44$ \\
\hline
\end{tabular}

Note. Chisq = chi square; GFI = goodness of fit index; AGFI = adjusted GFI; NFI = normed fit index; CFI = com-parative fit index; RMSEA = root mean square error of approximation; AIC $=$ Akaike's information criterion.

Table S2. Result of the confirmatory factor analysis for the 30-item and 20-item of MAAS-J.

\begin{tabular}{|c|c|c|c|}
\hline \multirow{2}{*}{ Item $\mathrm{N}$} & \multirow{2}{*}{ Items } & \multicolumn{2}{|c|}{ Factor Load } \\
\hline & & 30-item ver. & 20 -item ver. \\
\hline \multicolumn{2}{|c|}{ Factor 1: Discomfort with Ambiguity (DA) } & $\alpha=0.79$ & $\alpha=0.73$ \\
\hline 3 & It intensely disturbs me when I am uncertain of how my actions will affect others. & 0.509 & 0.651 \\
\hline 6 & I don't feel comfortable with people until I can find out something about them. & 0.325 & 0.514 \\
\hline 9 & I am just a little uncomfortable with people unless I feel that I can understand their behavior. & 0.418 & 0.527 \\
\hline 15 & It bothers me when I don't know how other people react to me. & 0.377 & 0.636 \\
\hline 18 & I always want to know what people are laughing at. & 0.113 & \\
\hline 21 & I get pretty anxious when I'm in a social situation over which I have no control. & 0.991 & \\
\hline
\end{tabular}




\section{Continued}

23 If I am uncertain about the responsibilities of a job, I get very anxious.

27 I enjoy carefully rehashing my conversations in my mind afterwards.

29 If I don't get the punch line of a joke, I don't feel right until I understand it.

0.279

1 There are two kinds of people in the world: the weak and the strong.

4 A person either knows the answer to a question or he doesn't. 


\section{日本語版 Multidimensional Attitude Toward Ambiguity Scale (21 item version)}

私たちは，生活の中で特定の状況に直面したときに，人々がどのょうに 反応するかに興味を持っています。このアンケートでは, あなたがこれら の状況を経験したときに，一般的にどのょうなことをしているのか，どの ように感じているのかを尋ねています，各項目については，他の項目とは 独立して回答するようにしてください。回答は，できるだけ自分に当ては まるょうに考えて選んでください. 正解も不正解もなく，「ほとんどの人」 がどう感じるかではなく，あなたにとって正確な回答を求めています．各 項目の $1,2,3,4,5,6,7$ の数字に○をつけて, それぞれについてあなたの感 じていることを表現してください.

$$
\begin{aligned}
& 1=\text { 全く同意しない } \\
& 2=\text { 同意しない } \\
& 3=\text { どちらかといえば同意しない } \\
& 4=\text { どちらともいえない } \\
& 5=\text { どちらかといえば同意する } \\
& 6=\text { 同意する } \\
& 7=\text { 強く同意する }
\end{aligned}
$$

1) 世界には弱者と強者という 2 種類の人間しかいない.

2) 私は人々が「これは到底, 理解できない」と言われる複雑な問題ほど追求してしまう。

3）自分の行動が他人にどのような影響を与えるかわからないときは, 激しく心が動摇する.

4) 人は答えを知っているか，知らないかのどちらかだ.

5) 私はその人の何かを知るまでは，一緒にいても落ち着かないことがある.

6) 世の中には「良い人」と「悪い人」の 2 種類がいる.

7）私は複数の解釈がとりうる状況に惹かれる.

8) その行動を理解できると思えないときは, その人たちといても少し安心できない.

9）ほとんどの場合，人は，正直者か曲者のどちらかに分けることができる.

10) 自分ではほとんどコントロールできない社会的状況にいると，かなり不安になる.

11）わかりやすい写実的な絵よりも, 曖昧さや印象からひも解くことを要するような絵に魅力を感じる.

12）他人が自分にどう反応するかわからない時はうんざりする.

13）私は曖昧であったり，そこに秘められた意味を好んだりする傾向がある.

14）多くの物事をな寸にあたり，そこには正しい道筋や誤った道筋がある.

15）いくつかの問題はとても複雑なので, それを理解しょうとするだけでも楽しい.

16）仕事に関する責任の所在がはっきりしていないと, とても不安になる.

17) 単純な問題を解決するよりも, 複雑な問題に取り組む方が楽しい.

18）人は $100 \% の$ 愛国心があるか，まったくないかのどちらかだ.

19）とても曖昧といえるほどまでに複雑な問題に取り組むのが楽しい.

20) ジョークのポイントをつかめないときは，それがわかったと思えるまでもやもやする. 